\title{
Water Balance of Mediterranean Quercus ilex L. and Pinus halepensis Mill. Forests in Semiarid Climates: A Review in A Climate Change Context
}

\author{
Eduardo Vicente ${ }^{1, *}$, Alberto Vilagrosa ${ }^{2}$ (D), Samantha Ruiz-Yanetti ${ }^{3}$, Àngela Manrique-Alba ${ }^{4}$, \\ María González-Sanchís ${ }^{5}$, Hassane Moutahir ${ }^{1}{ }^{10}$, Esteban Chirino ${ }^{6}$, Antonio del Campo ${ }^{7}$ \\ and Juan Bellot ${ }^{1}$ \\ 1 IMEM Ramón Margalef, Department of Ecology, Faculty of Sciences, University of Alicante, \\ 03080 Alicante, Spain; hassane.moutahir@ua.es (H.M.); juan.bellot@ua.es (J.B.) \\ 2 Center for Environmental Studies in the Mediterranean (CEAM Foundation), Joint Research Unit \\ University of Alicante-CEAM, University of Alicante, 03080 Alicante, Spain; a.vilagrosa@ua.es \\ 3 Institute of Environmental and Ecological Sciences (ICAE), University of the Andes, Mérida 5101, Venezuela; \\ samanthar@ula.ve \\ 4 Aula Dei Experimental Station (EEAD-CSIC), Avda. Montañana 1005, 50059 Zaragoza, Spain; \\ amanrique@eead.csic.es \\ 5 Department of Hydraulic Engineering and Environment, Polytechnic University of Valencia, \\ 46022 Valencia, Spain; magonsa2@upvnet.upv.es \\ 6 Faculty of Agricultural Sciences, Lay University Eloy Alfaro of Manabí, Ave. Circunvalación, Vía San Mateo, \\ Manta 130802, Ecuador; esteban.chirino@gmail.com \\ 7 Department of Hydraulic Engineering and Environment, Research Group in Forest Science \\ and Technology (Re-ForeST), Polytechnic University of Valencia, 46022 Valencia, Spain; ancamga@upv.es \\ * Correspondence: ev.bartoli@ua.es; Tel.: +34-965-903-373
}

Received: 5 June 2018; Accepted: 12 July 2018; Published: 16 July 2018

check for updates

\begin{abstract}
Forests provide many environmental services, especially those related to the water cycle. In semiarid areas where water is a limiting factor for ecosystem functioning, forested areas can have a strong impact on ground water recharge. In these areas, proper knowledge of forests' water balance is necessary to promote management practices that may ensure ecosystem properties and environmental services like water or carbon fixation. In this article, we review several ecohydrology topics within the framework of Mediterranean water-limited environments in two representative ecosystems: Kermes oak (Quercus ilex L.) and Aleppo pine (Pinus halepensis Mill.) forests. Both are the commonest species in countries that surround the Western Mediterranean Basin. We analysed the Blue and Green water components, i.e., green water is the water demand of forests, represented by evapotranspiration and interception; while blue water is the part of the balance involving runoff and deep percolation, which can be regarded as water directly usable by society. In general, different studies conducted in Mediterranean areas have pointed out that the water balances of $Q$. ilex and $P$. halepensis forests have low values for the Blue to Green water (B/G) ratios. Adaptive forest management like forest thinning can compensate for these ratios. Thinning has demonstrated to reduce losses by interception, but at same time, it can also increase individual tree transpiration and evaporation rates. However, these practices lead to higher B/G ratios when considering the whole stand. In future global change scenarios, in which drought conditions are expected to intensify, management practices can improve the water balance in these ecosystems by minimizing the risk of plant mortality and species replacement due to intense competence by water resources.
\end{abstract}

Keywords: drought; blue water; green water; groundwater recharge; silviculture; global change projections 


\section{Introduction}

Forests provide many environmental services, especially water-cycle related ones. Forested areas are capable of reducing the flood risk and protecting soil from erosion, mainly due to higher interception, infiltration, and evapotranspiration rates than in non-forested areas [1-3]. They are also capable of producing other resources, like wood, fruits, and seeds, or even acting $\mathrm{CO}_{2}$ sinks [4].

However, in semiarid environments, where water is a limiting factor for ecosystem functioning, it is generally considered that forested areas have a negative impact on water availability given the reduction in streamflow and ground water recharge (blue water) [5,6], and therefore, in the water used directly by society. However, they are still able to enhance biodiversity and provide important aesthetic values [7]. Notwithstanding, a new paradigm maintains that, even for arid zones, there is an optimum tree cover that improves water availability [8]. Therefore, in these areas, proper knowledge about forests' water balance is necessary to promote management practices that may ensure both ecosystem stability and environmental services.

According to climate change projections, a general increase in temperature is expected [9], which may have important impacts on forests. In fact, a rising temperature and changes in precipitation regimes have already been related to dieback and forest decay processes worldwide [10,11]. In semiarid zones, like the Mediterranean Basin, this increment in temperature is expected to happen along with reduced rainfall, and would lead to more frequent extreme droughts [12].

Mediterranean species have several mechanisms and ontogenetic adaptations to drought because lack of water in the Mediterranean has been an evolutionary driver [13]. However, especially intense or lasting episodes of drought can trigger events of decay or mortality that could lead to species shifting processes and forest cover alterations which would, in turn, promote those functional strategies to be more tolerant to drought conditions vs. those that are not [14,15]. These alterations may have an impact on all the above-mentioned forests' environmental services, particularly water cycle-related ones. For this reason, studying forests' water balance in semiarid zones and a better understanding of its drivers are especially relevant for developing sustainable water management policies.

The aim of this paper is to review the ecohydrological components of forested areas located in dry and semiarid areas, such as those in southeast Spain, formed by Quercus ilex L. and Pinus halepensis Mill. forests. These two evergreen trees commonly co-occur in Mediterranean forests [16,17], but usually they form monospecific forests of $P$. halepensis, a pioneer coniferous species with a high germination rate after disturbances like wildfires, and the $Q$. ilex tree, which is a late successional evergreen hardwood tree.

In this article, we have reviewed the main topics related to the forest ecohydrology of water limited ecosystems, from the functional characteristics of each species that faces water scarcity and the water balance's main characteristics for forests stands in arid and semiarid environments, to the role of hydrology-oriented silviculture practices to promote a better management of water yield, including the potential effects of the estimated climate scenarios on these water balances.

\section{Plant Functional Characteristics and Strategy to Cope with Drought}

Plant traits determine the functional characteristics of plants and how they respond to the environment [18-20]. Functional traits, such as life form (tree, shrubs, herbaceous), life habits (evergreen, semi-deciduous, and deciduous), branching architecture, leaf area, specific leaf area, or hydraulic conductivity, establish differences in the structure of a forest and, consequently, in the soil water balance in several vegetation types [21]. Forest canopy characteristics also determine the volume of water flows across a vegetation canopy, such as interception, stemflow, and throughfall [22]. Soil characteristics, such as soil bulk density, soil particle size, porosity, field capacity content, or wilting point moisture content, will also determine water availability for plants and, therefore, the water flows from the surface to the water table [23]. In addition to above ground traits, plant belowground traits, like root system morphology or rooting depths, are key factors that determine water uptake patterns and transport to aerial plant parts [24]. 
Both $Q$. ilex and P. halepensis are typical Mediterranean species with an evergreen life form. However, some morphological differences will establish different plant hydrological responses. P. halepensis is a conifer with two needles per brachyblast, while $Q$. ilex has a flat sclerophyllous leaf blade (Table 1). These leaf characteristics (i.e., flat and larger leaf size and needle for Q. ilex and P. halepnesis, respectively), with differences in the degree of sclerophylly, produce a leafy canopy type which, along with differences in the conducting system and branching architecture, would cause some differences in the water flow through the canopy between both species [25]. As regards the belowground structure, $P$. halepensis presents a moderate to shallow root system that determines the capacity to acquire water from soil (Table 1). In contrast, Q. ilex has a deep root system [26] that it uses to explore and draw water from deep soil layers [24]. In spite of the morphological differences between these species, forest characteristics (tree density, basal area, vegetation cover, species composition and structure, etc.) are also variables that determine the water flow through a canopy and the soil water balance results [23,27]. In this context, differences in the depth and volume of the explored soil layers, and finally, in the soil water balance between Mediterranean pine forests and $Q$. ilex forests, should be expected.

Table 1. Morpho-functional traits and strategies of resistance to water deficit between Pinus halepensis and Quercus ilex.

\begin{tabular}{|c|c|c|c|}
\hline & & P. halepensis & Q. ilex \\
\hline \multicolumn{4}{|l|}{ Plant functional traits } \\
\hline Life form & & Tree & Tree \\
\hline Leaf habits & & Evergreen & Evergreen \\
\hline Life histories & & Seeder & Resprouter \\
\hline Plant height & & $15-20 \mathrm{~m}$ & $8-25 \mathrm{~m}$ \\
\hline & & Isohydric species & Anisohydric species \\
\hline Functional strategy to cope drought & & Drought avoidance & Drought-tolerant \\
\hline \multicolumn{4}{|l|}{ Cel-water relationships } \\
\hline$\Psi_{\text {tlp }}$ & $-\mathrm{MPa}$ & 2.2 & 3.9 \\
\hline$\Pi_{\mathrm{o}}$ & $-\mathrm{MPa}$ & 1.7 & 2.8 \\
\hline$E_{\max }$ & $-\mathrm{MPa}$ & 13 & 13 \\
\hline WSD $_{\text {tlp }}$ & $\%$ & 17 & 30 \\
\hline Gs $\max$ & $\mathrm{mmol} \mathrm{m} \mathrm{m}^{-2} \mathrm{~s}^{-1}$ & 270 & 250 \\
\hline Stomata closure at midday & & Strong & Moderate \\
\hline Photochemical efficiency PSII & & Low photoinhibition & High photoinhibition \\
\hline SLW & $\mathrm{mg} \mathrm{cm}^{-2}$ & 18.5 & 21.0 \\
\hline Lethal leaf temperature & ${ }^{\circ} \mathrm{C}$ & 50 & 45 \\
\hline \multicolumn{4}{|l|}{ Xylem conducting system } \\
\hline $\mathrm{D}_{\max }$ & $\mu \mathrm{m}$ & 13.6 & 16.7 \\
\hline $\mathrm{PLC}_{50}$ & & -4.7 & -5.5 \\
\hline LSC & $\mathrm{m}^{2} \mathrm{MPa}^{-1} \mathrm{~s}^{-1} 10^{-8}$ & 9.54 & 5.96 \\
\hline Ks & $\mathrm{m}^{2} \mathrm{MPa}^{-1} \mathrm{~s}^{-1} 10^{-4}$ & 1.52 & 1.04 \\
\hline \multicolumn{4}{|l|}{ Root system } \\
\hline Rooting depth & & Medium/Deep & Deep \\
\hline $\mathrm{R} / \mathrm{S}$ & & Low & High \\
\hline $\mathrm{kh}_{\text {root }}$ & $\mathrm{kg} \mathrm{s}^{-1} \mathrm{~m}^{2} \mathrm{MPa}^{-1} 10^{-4}$ & 0.42 & 2.49 \\
\hline
\end{tabular}

Adapted from Vilagrosa et al. [28], with modifications. Legend: $\Psi_{\text {tlp }}$, water potential at the turgor loss point; $\Pi_{0}$, osmotic potential at full turgor; $E_{\max }$, cell wall elasticity modulus; WSDtlp, water saturation deficit upon turgor loss; $\mathrm{Gs}_{\max }$, maximum stomatal conductance values at full hydration; SLW, specific leaf weight; PLC $\mathrm{C}_{50}$, water potential at $50 \%$ loss of hydraulic conductance; $\mathrm{D}_{\max }$, vessel or tracheid average diameter; LSC, leaf specific conductivity; Ks, shoot-specific conductivity; R/S, root to shoot ratio; $\mathrm{Kh}_{\text {root, }}$, whole root system hydraulic conductivity. See the reference list in the Supplementary file.

Under dehydration conditions, the drought resistance strategy is the ability to maintain plant functionality and, ultimately, plant survival [29]. Indeed, it has been pointed out that plants can adopt two main functional strategies to face drought: isohydric and anisohydric plant responses [30-32]. Isohydric plants keep the water potential relatively stable, independently of environmental conditions and soil water fluctuations. In contrast, anisohydric species track environmental fluctuations in water availability with a variable water potential according to water availability [33,34]. Iso- and anisohydric 
strategies have been linked to water use and drought resistance strategies, such as drought avoidance and drought tolerance $[20,29]$. In this context, species such as $Q$. ilex, which allow their tissues to dehydrate as water availability declines, present drought tolerance or dehydration tolerance [29]. These species have specific functional characteristics and mechanisms related to an anisohydric response, and are able to tolerate more intense stressful conditions as cell-water relationships focus on delayed stomatal closure (Table 1). They also present moderate stomatal control at midday and allow photoinhibition processes. Another relevant issue to this strategy is resistance to xylem cavitation. In general, these species display high xylem cavitation resistance with a moderate water flow through stems (i.e., low-moderate leaf specific conductivity, LSC), which determines moderate gas exchange rates [20,35].

At the opposite end of this spectrum, we find plant species that strictly regulate water losses to avoid dehydration (drought avoidance or dehydration avoidance strategy; [29]). This strategy is used by isohydric plants (Table 1). P. halepensis has been assessed as adopting an isohydric strategy that maintains efficient stomatal regulation by avoiding water deficit according to a water saver mechanism and moderate photoinhibition [28,36-39]. P. halepensis also shows low resistance with a high water deficit, as evidenced by lower to moderate xylem cavitation resistance compared to Q. ilex [19]. $P$. halepensis needles lose turgidity at relatively high leaf water potentials $(-2.2 \mathrm{MPa}$, corresponding to a cellular water content that comes close to $83 \%$ ), while $Q$. ilex displays stomatal closure at $-3.9 \mathrm{MPa}$ (Table 1). In contrast, $Q$. ilex has been assessed as a drought-tolerant anisohydric species $[20,36]$ with delayed stomatal closure to allow gas exchange rates under more intense drought conditions. This species presents a lower water supply capacity to leaves (low leaf-specific conductivity, LSC), but excellent resistance to xylem cavitation, which are considered tolerance mechanisms $[19,20]$. In addition, $Q$. ilex mainly presents dehydration tolerance mechanisms, but also has avoidance mechanisms, such as deep rooting, to allow water absorption in dry summer months. These different functional strategies and functional mechanisms reflect the wide array of variety in functional traits that distinct species can develop to adapt to the environment and to produce differences in the soil water balance depending on which species dominates in ecosystems.

\section{Water Balance in Quercus ilex Forests}

The climate range of $Q$. ilex goes from semi-arid to humid environments, where the former are considered marginal forests. Most $Q$. ilex forests are restricted to upper catchment environments, where local hydrological characteristics may be very important for downstream water availability. In humid environments, their influence reaches $30 \%-60 \%$ of downstream freshwater, while this role in semiarid to arid environments rises to $70 \%-95 \%$ [40]

Despite the fact that the water contribution of these forests to lower catchment areas is significant, their water consumption is also relevant, which usually leads to a blue-green water ratio (B/G) below the unit. This range widely varies with climate range, and lowers when moving from humid to semi-arid environments. Limousin et al. [41] studied a humid Q. ilex forest and obtained a B/G ratio of 0.55 , which lowered to 0.29 when $33 \%$ of the throughfall was excluded, although both values could be overestimated as soil evaporation was not considered. Following the climate range, Joffre et al. [42] reported lower B/G values in three sub-humid catchments, with B/G ratios going from 0.32 to 0.44. Similarly, Bellot et al. [27] studied a sub-humid catchment and obtained a B/G ratio of 0.23 when studying a catchment with $Q$. ilex as the main forest species.

Thus, when continuing with the climate gradient of the $Q$. ilex $\mathrm{B} / \mathrm{G}$ ratio, very little information can be found about the $\mathrm{B} / \mathrm{G}$ ratio of semi-arid $Q$. ilex forests, and most of it only refers to dehesas systems, i.e., typical Mediterranean pasture in some places of southwest Spain mixed with big $Q$. ilex trees. Ceballos and Schnabel [43] calculated the water balance of a semi-arid catchment in a dehesa land use and obtained a low B/G ratio that ranged from 0.01 to 0.2 , which could have been underestimated as no deep percolation was considered. Likewise, Campos et al. [44] used satellite information to calculate the water balance of a semi-arid dehesa and reported an average B/G balance of 0.2 over five years. On the contrary, only one study has reported a water balance of a semi-arid natural $Q$. ilex 
forest [45]. Its results are summarized in Table 2, with B/G ratios below the unit for both years, where evapotranspiration (ET) appears to consume most water, and the blue water contribution is basically produced by deep drainage, with almost negligible runoff and streamflow [45]. The results from both the dehesas system and the natural $Q$. ilex forest, are consistent with the typical response of semi-arid ecosystems. In this systems, ET usually dominates the global stand water balance, followed by canopy interception, and blue water contribution occurs mainly after strong precipitation events [45,46]. Both formations show high seasonality in the $\mathrm{B} / \mathrm{G}$ ratio, where the maximum water contribution takes place in fall and winter (Figure 1). Despite this, there is one period when B/G exceeds the unity in both environments, where the low values indicate the scarce water contribution of semi-arid $Q$. ilex forests and the high water requirements to maintain them. This scarce water contribution and high water demand highlight the marginality of some coppice forests, and, therefore, their difficulty when facing the warmer and drier climates conditions expected to occur in the future in the Mediterranean Basin [12].

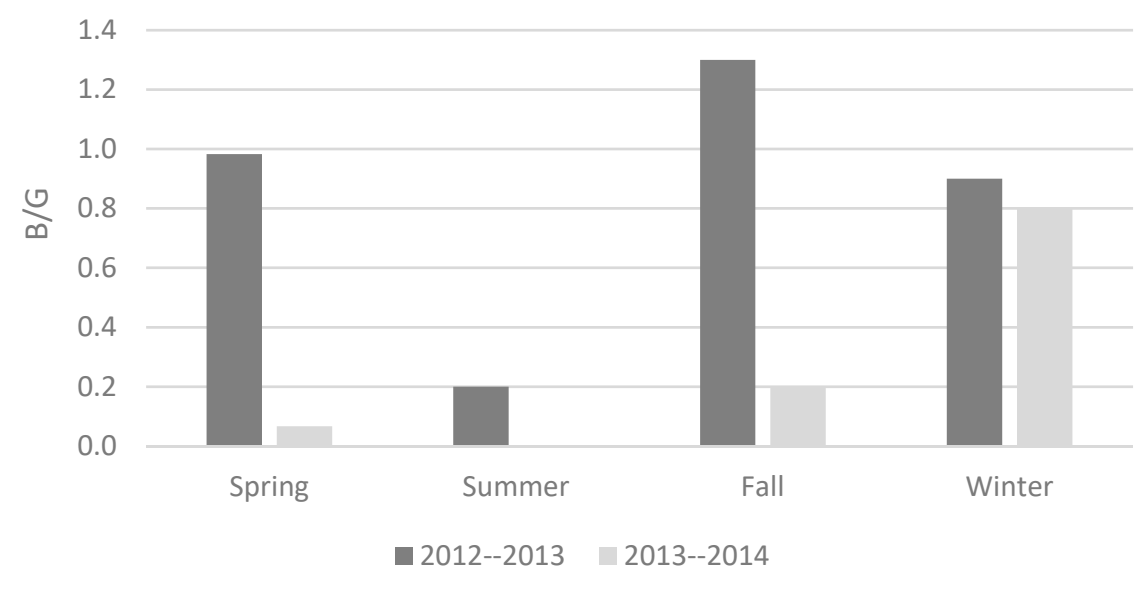

Figure 1. The blue to green water (B/G) ratio for a Q. ilex coppice forest in 2012-2013 and 2013-2014. Precipitation values were $534 \mathrm{~mm}$ and $271 \mathrm{~mm}$ for 2012-2013 and 2013-2014, respectively.

When expressing ET as a \% of gross precipitation, the values in both ecosystems are similar to those obtained in more humid $Q$. ilex forests [41,47]. On the contrary, when absolute ET values are considered (depth, $\mathrm{mm}$ ), the ET of the semiarid forests does not even reach the transpiration rate of the humid Q. ilex forests [41,47]. Nevertheless, the values are similar to that of a low-density woodland during a drought period $(191 \pm 20 \mathrm{~mm})$ reported by Infante et al. [48]. The fact that the transpiration of a sub-humid low density forest under drought conditions is comparable to that of a semiarid one, indicates the adverse conditions that these forest have to face, which are even harder for natural Q. ilex forests as tree competence is stronger. 
Table 2. Water balance of Pinus halepensis and Quercus ilex forests in two water years, 2012-2013 and 2013-2014, which are respectively wet and dry. P is gross precipitation, ET + Int is evapotranspiration and interception, $R_{\text {off }}$ is runoff, and $\mathrm{R}$ is potential deep drainage. $\mathrm{B} / \mathrm{G}$ represents the blue to green water ratio. Adapted from Ruiz-Yanetti [49] and del Campo et al. [43]. Site names: Mela (MEL), Cabeço d'or (CAB), Ventós (VEN), Sierra de Águilas (SAG).

\begin{tabular}{|c|c|c|c|c|c|c|c|}
\hline Years & Species & Site Name & $\mathbf{P}(\mathbf{m m})$ & $\begin{array}{c}\mathrm{ET}+\text { Int } \\
(\%)\end{array}$ & Roff (\%) & R (\%) & $\mathrm{B} / \mathrm{G}$ \\
\hline \multirow{5}{*}{ 2012-2013 } & & MEL & 911 & 72 & 0.5 & 27.6 & 0.39 \\
\hline & P. & $\mathrm{CAB}$ & 417 & 82.1 & 0.4 & 17.6 & 0.22 \\
\hline & halepensis & VEN & 425 & 79.9 & 0.3 & 19.8 & 0.25 \\
\hline & & SAG & 420 & 79.4 & 0.3 & 20.3 & 0.26 \\
\hline & Q. ilex & & 534 & 51 & 0 & 49 & 0.9 \\
\hline \multirow{5}{*}{ 2013-2014 } & & MEL & 318 & 91.1 & 0.4 & 8.5 & 0.1 \\
\hline & $P$. & $\mathrm{CAB}$ & 146 & 95.1 & 0.4 & 4.6 & 0.05 \\
\hline & halepensis & VEN & 114 & 97.8 & 0.2 & 2 & 0.02 \\
\hline & & SAG & 142 & 91.4 & 0.3 & 8.3 & 0.09 \\
\hline & Q. ilex & & 271 & 81 & 0 & 19 & 0.2 \\
\hline
\end{tabular}

The $B / G$ ratios show high seasonality when compared over a one-year period, where the maximum water contribution takes place in spring and fall. Despite there being one period when B/G exceeds the unity (Figure 1), the low values indicate the scarce water contribution of marginal $Q$. ilex forests and high water requirements to maintain them. This scarce water contribution and high water demand highlight the marginality of some coppice forests and, therefore, their difficulty when facing the warmer drier climate conditions expected to occur in the future in the Mediterranean Basin [12].

\section{Water Balance in Pinus halepensis Forests}

P. halepensis forests also show a highly variable $\mathrm{B} / \mathrm{G}$ rate that ranges from 0.8 to 0.06 , according to a rainfall gradient that increases with precipitation $[21,46,49]$. The $P$. halepensis stands under these climatic conditions usually show a high percentage (referring to annual rainfall) of green water, above $90 \%$ [49], which can rise to $100 \%$ during especially dry years when annual precipitation drops to $260 \mathrm{~mm}$ [50]. In these cases, it can be even higher than $100 \%$ due to the use of water stored in deeper soil layers [51,52].

As formerly addressed, this species has been widely used for afforestation purposes, even in quite arid areas where annual rainfall barely exceeds $300 \mathrm{~mm}$ [53]. This has posed questions about the sustainability of these forests under such dry conditions, which have led to current water balance studies to analyze their sustainability. In fact, it has been regarded that afforestation significantly impacts local water balances, by presenting higher evapotraspiration values than the non afforested areas adjacent to them. In line with this, Rohatyn et al. [2] studied the effects of $P$. halepensis afforestation on the water yield along a semiarid climatic gradient. These studies point out that when this afforestation is located in more humid environments, it displays marked decreases in water yields, nearly $30 \%$ of precipitation, which means $200 \mathrm{~mm} /$ year in absolute terms. However, in dry-land afforestation, this reduction in water yield lowers by about a $20 \%$ and involves $50 \mathrm{~mm} /$ year, which indicates that the effect of $P$. halepensis afforestation on the water balance varies with climate. There are more studies that have addressed this response of afforestation to climate variability. Helman et al. [3] have found that higher values of water use efficiency are reached in dry land afforestation of P. halepensis. The same has been observed for other Pinus species present in semiarid environments, like P. brutia and P. pinea. In addition, it is noteworthy that stands located in these climates show ecohydrologycal and ecophysiological adjustment to drought, which leads to stronger resilience to these conditions in comparison to other stands located in more humid places [54-56].

In order to continue with this climate response, Ruiz-Yanetti [57] calculated the water balance of four P. halepensis stands with the HYDROBAL ${ }^{\circledR}$ model [58-60] for a three-year study period. These stands had tree densities that ranged from 489 to 968 trees ha ${ }^{-1}$, and were located along a rainfall 
gradient (from $300 \mathrm{~mm}$ to $610 \mathrm{~mm}$ ) in the province of Alicante (southeast Spain). Their results indicated high variability between two selected wet and dry years (Table 2); and low values of B/G ratios and the green water fluxes reached percentages above $90 \%$ total rainfall under water scarcity conditions.

Considering the whole study period, they found significant differences in the mean values of Interception (Int) and net precipitation (Pnt) between the sites with different vegetation covers (Figure 2). These results suggest their strong influence on water balance and agree with the idea that in afforested areas with a high tree density, interception reaches high values that can emphasise drought stress under water limitation conditions [61]. They also found that actual evapotranspiration (Eta) was significantly higher, more than $54 \%$ of total precipitation, in those places where tree density was lower. This effect was also observed by several authors $[28,39,62]$ who indicated that the amount of water transpired for one tree was prone to be higher than that transpired by a stand because an individual tree frequently has more biomass for its maintenance and could be affected by high potential evapotranspiration.
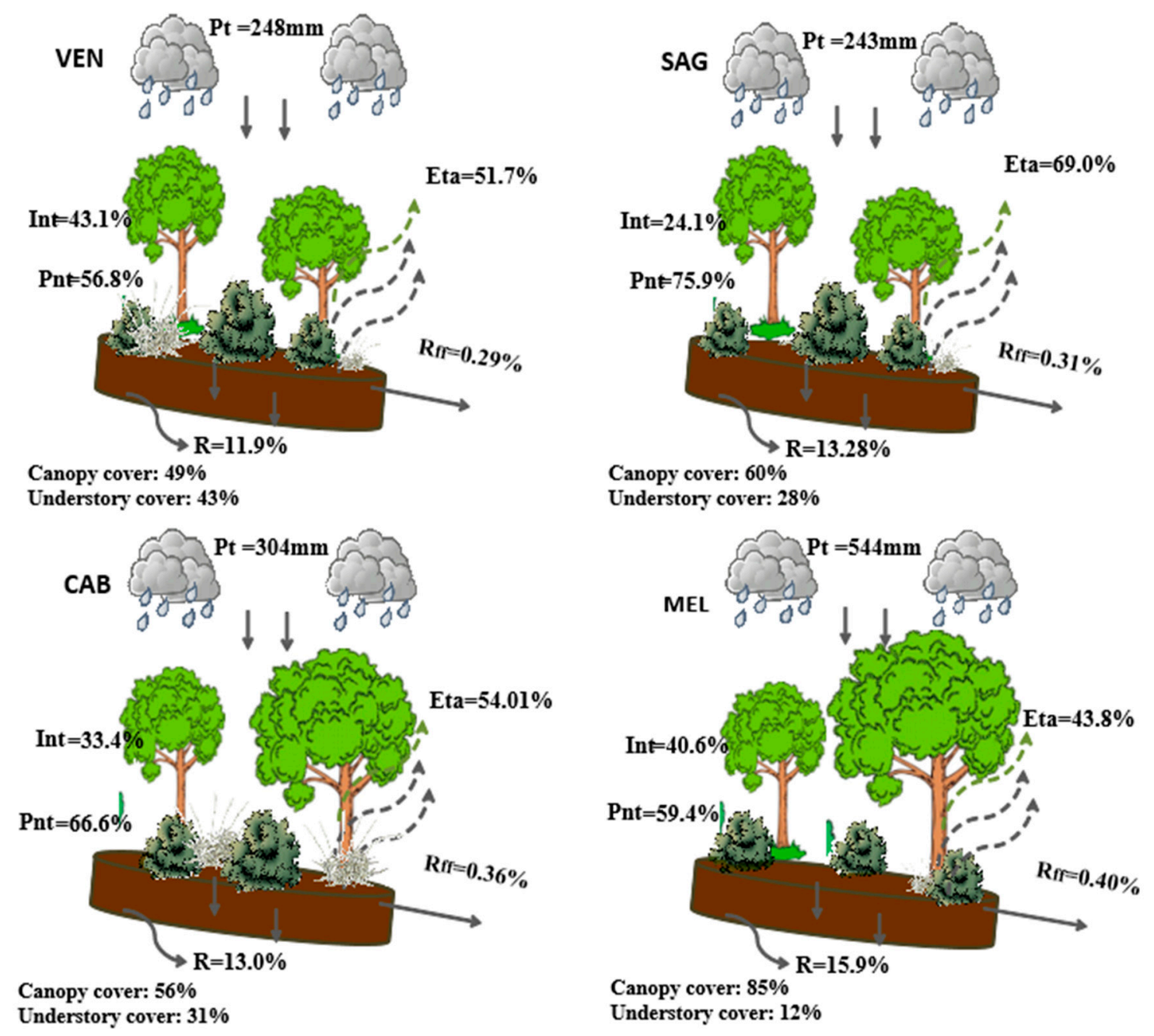

Figure 2. Water balance diagrams in the different forests along a gradient of precipitation. The water flow values estimated by the HYDROBAL ${ }^{\circledR}$ model according to the pine afforestation obtained at each site. Values are a percentage (\%) in relation to total precipitation. Abbreviations: Net precipitation (Pnt); Interception (Int); Runoff (Rff); actual evapotranspiration (Eta); potential recharge (R). Site names: Ventós (VEN); Sierra de Águilas (SAG), Cabeço d'or (CAB); Mela (MEL).

\section{The Role of Mediterranean Forests in Aquifer Recharge for Semiarid Areas}

In most semiarid areas, droughts and scarce rainfall often turn groundwater into the main source of freshwater. In southeast Spain, approximately $80 \%$ of the water demand for society is supplied 
from aquifers. In recent decades, the pressure placed on this resource has grown due to the increasing population in these areas and to lack of precipitation associated with drought intensity, which is even expected to grow with climate change [63]. Therefore, hydrological management is an important tool to protect water resources in these areas and also to gain a better understanding of aquifer recharge.

Aquifer recharge depends on several factors, such as geology, climate conditions, and the type of land cover in each catchment [58,64]. Several studies have demonstrated that the main driver with a direct impact on aquifer recharge is rainfall [19,58,63,64]. Indeed, strong linear relationships between rainfall and aquifer recharge have been found for semiarid areas, with correlation coefficients up to 0.9 [65]. It is important to mention that for semiarid zones, most rainfall events present quite a low intensity and a short duration, and very few are able to have any real influence on aquifer recharge. In fact, Andreu et al. [66] found that only those events with over $15 \mathrm{~mm}$ were able to produce an effective recharge, which represents only $9 \%-17 \%$ of the total amount of precipitation recorded during their study period. This also implies a high seasonality for recharge events as many rainfall episodes occur in spring and autumn.

It is also noteworthy that the existing soil water content before a rainfall event has a relevant influence on deep drainage. In fact, the higher it is in previous soil moisture, the higher recharge events are [19,64]. Vegetation, therefore, also plays an important role in recharge. Most forested areas have a negative impact on blue water fluxes, but are capable of reducing the risk of erosion and floods. Bellot et al. [59] found that forested areas reduced recharge fluxes by $36.9 \%$ in semiarid areas due to a higher evaporative demand, with shrub stands being the most favourable for aquifer recharge. Likewise, Ruiz-Yanetti [57] studied the role of the most representative vegetation covers and plant vertical structure located in aquifer recharge areas in southeast Spain. These authors found that forested stands with more stratification and structure complexity reduced both soil water content and recharge due to increased interception and evapotranspiration. They concluded that the more favourable landscape structure to promote aquifer recharge in these areas would be $16 \%$ of the surface covered with shrubs and $P$. halepensis with low levels of stratification, while the rest of the surface would be covered with plenty of tussocks like Stipa tennacisima.

\section{Forest Management Effects on the Transpiration of Mixed Forests}

Hydrology-related silviculture has been proposed to adapt forests to climate changes [67]. In Mediterranean forests, it could be a useful tool to both ensure ecosystem resilience and blue water incomes under more water scarce conditions. In P. halepensis stands, it has been observed that thinning practices can reduce water losses by interception. These practices also increment the use of water by the remaining trees, but transpiration at the stand level is lower than in non-thinned stands $[46,68,69]$.

When considering mixed $Q$. ilex and P. halepensis forests, the different strategies in seasonal transpiration patterns and the ability to acquire water at different soil depths or soil water contents may condition the species' co-existence [70,71]. Del Castillo et al. [72] observed that both species used the same amount of water during the wet season, which also occurs in the growing season, but shifted to distinct water sources during the summer drought period. David et al. [73] reported that the deep root system of $Q$. ilex (up to $13 \mathrm{~m}$ ) allows this species to access groundwater and to, therefore, remain physiologically active during summer drought periods. Meanwhile, pine species tend to rely more on shallow soil moisture during summer drought periods by following a drought avoidance strategy and by limiting water flows to the atmosphere [74]. Furthermore, this difference in the water uptake depth appears to be stimulated in mixed forests because $Q$. ilex surrounded by P. halepensis explores deeper water sources than in monospecific formations [72].

Experimental results that support the differentiated water uptake strategies in $Q$. ilex and P. halepensis in a mixed forest are also presented in this review (Figure 3). Tree transpiration was measured in both species co-occurring in a semiarid mixed forest two years after a thinning silvicultural treatment (see [45] for experiment details). The comparison showed significantly higher tree transpiration values in $Q$. ilex than in P. halepensis, where the biggest differences were from early summer to late autumn 
periods (Figure 3). Likewise, a negative linear relationship $\left(R^{2}=0.71\right)$ was found between the oak and pine transpiration ratio (ln $\mathrm{T}_{\text {oak }} / \mathrm{T}_{\text {pine }}$ ) and the soil water content during the growing season, which indicates that $Q$. ilex obtained a higher transpiration rate with a lower soil water content. Conversely, this relationship became non-significant after the growing season.

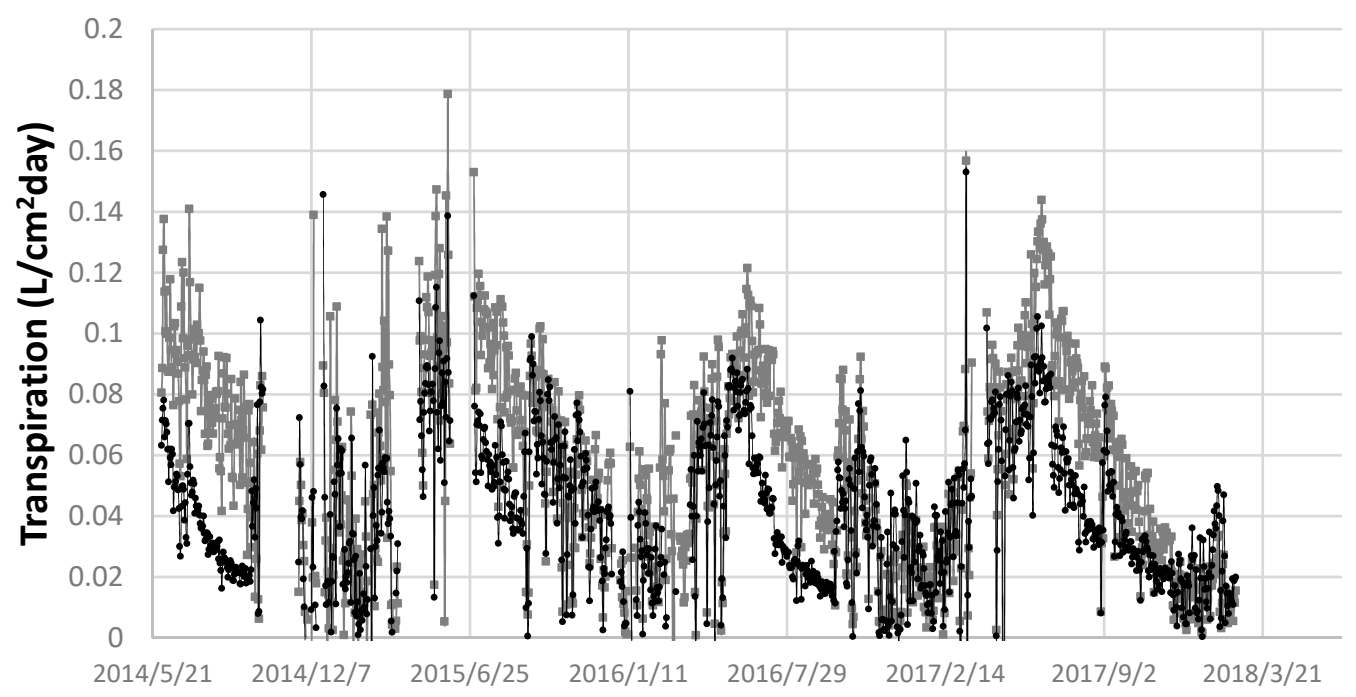

Figure 3. Transpiration (litres per $\mathrm{cm}^{2}$ of sapwood area per day) of Q. ilex (grey) and P. halepensis (black) during the study period.

In agreement with these results, several studies [74-77] have suggested that the ordinary soil depth at which most water is taken up in pines is $30-40 \mathrm{~cm}$, while $Q$. ilex appears to reach deeper soil layers [72,73]. Indeed, the use of a deeper water source by $Q$. ilex would also explain it being able to maintain higher transpiration rates during drought periods. Likewise, according to these results, the early effects of forest management do not appear to alter the differentiated strategies of both species, but only to increase their water consumption [45].

\section{Future Scenarios in a Global Change Context}

Most climate models estimate an increase in temperature and a reduction in precipitation over the 21st century for the Mediterranean Region [9]. These changes have already been observed in recent decades for this region [9], particularly for the Iberian Peninsula [78,79]. On a local scale, specifically in the province of Alicante (southeast Spain), precipitations have shown a negative trend ( $-9.4 \mathrm{~mm} /$ decade) over the last six decades until 2012. The mean temperature significantly has shown a positive increment $\left(+0.18{ }^{\circ} \mathrm{C} /\right.$ decade, $\left.p<0.001\right)$ during the same period [80]. In the future, and according to nine CMIP5 (Coupled Model Intercomparison Project Phase 5) climate models, reductions of $30 \%$ and $40 \%$ in mean precipitations are expected under climate scenarios RCP4.5 and RCP8.5 (Representative Concentration Pathways 4.5 and 8.5), respectively, for the 2040-2099 period with respect to the 1953-2012 period. Temperature is expected to rise at the same observed rate $\left(+0.2 \pm 0.07{ }^{\circ} \mathrm{C} /\right.$ decade $)$ under the moderate climate scenario $\mathrm{RCP} 4.5$, and at a higher rate $\left(+0.73 \pm 0.18^{\circ} \mathrm{C} /\right.$ decade $)$ under the high scenario RCP8.5 during the 2040-2099 period [80].

The observed and expected changes in temperature and precipitation will have marked effects on ecosystems. According to Rivas-Martínez's [81] classification, using precipitation thresholds, bioclimatic belts will shift to the north, and the semiarid belt will cover a more extensive territory (Figure 4A) [80]. By the end of the 21st century, and with extreme climate scenarios, the subhumid belt is likely to disappear in the province of Alicante (Figure 4B), and the arid and semiarid belts are expected to cover more territory, both locally and globally (Figure $4 \mathrm{~A})[78,80,82]$. These changes will have important effects on water balances. Moutahir [80] used the above-cited projected data and 
the eco-hydrological HYDROBAL ${ }^{\circledR}$ model to simulate the water balance in three pine forests that are representative of each bioclimatic belt in the province of Alicante (semi-arid, dry, subhumid). This author showed that negative trends are expected in the different water balance components, especially for the stands located on the subhumid belt, which is most likely to disappear in the future under the extreme climate scenarios (Figure 5).

(A)

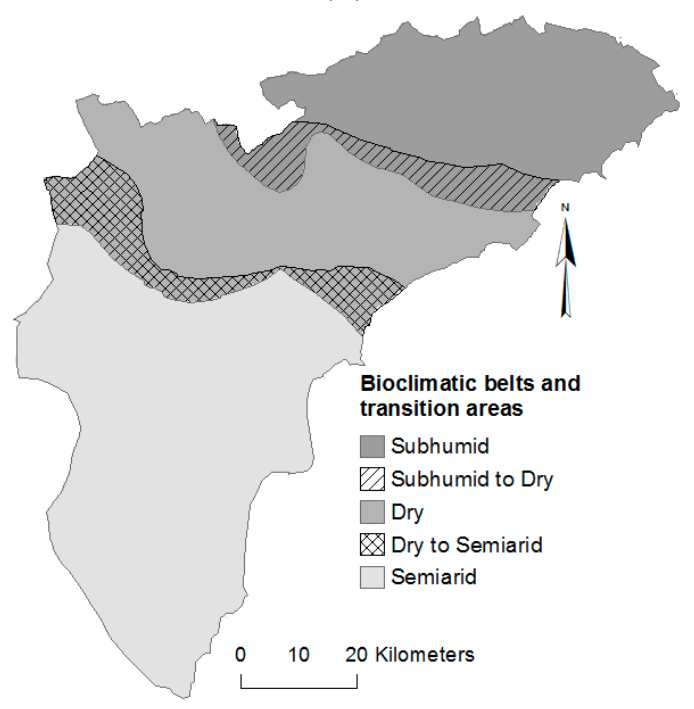

(B)

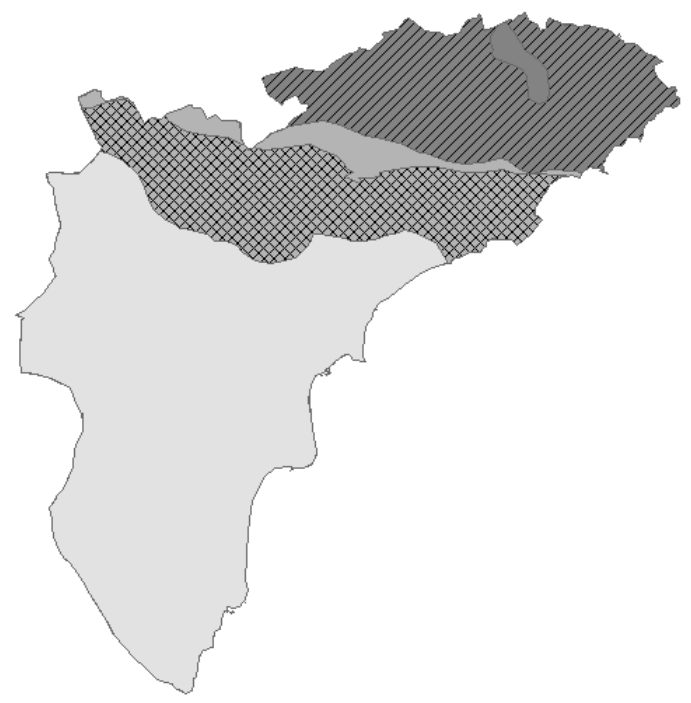

Figure 4. Shifts of the bioclimatic belts in the province of Alicante. (A) Changes observed between 1953-1982 and 1983-2012 (dashed areas show transition zones). (B) Changes estimated for 2070-2099 with respect to 1983-2012 period according to the high scenario RCP8.5 (Representative Concentration Pathways 8.5) (the average of nine CMIP5, Coupled Model Intercomparison Project Phase 5, climate models).

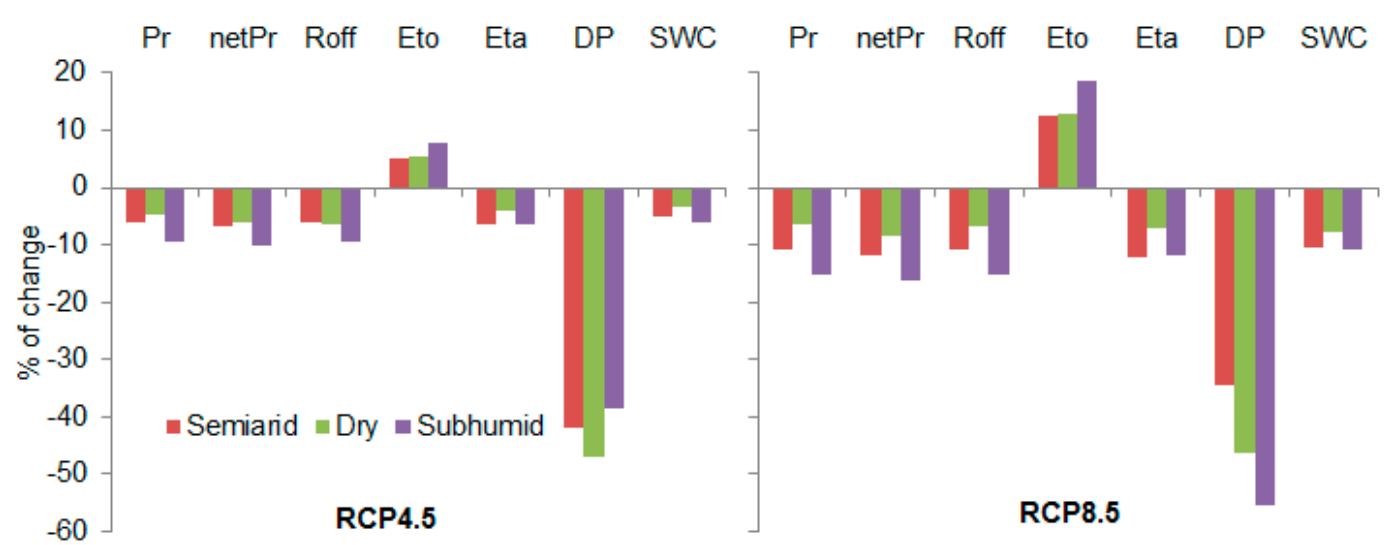

Figure 5. Percentage of change in the water balance components during the 30-year 2070-2099 period compared to 2010-2039 at the three pine sites along a climate gradient under the two RCP scenarios and in nine CMIP5 climate models. Pr: Precipitation, netPr: Net rainfall, Eto: reference evapotranspiration, Eta: actual evapotranspiration, DP: deep percolation, SWC: soil water content.

However, changes in the mean are not the only concern in the Mediterranean Region. Indeed, changes in the frequency, intensity, size, and temporal distribution of climate extremes are expected in this region [9], and will have different effects on water balance. Groundwater recharge in arid and semiarid environments is often restricted to heavy rainfall events [83]. However, the number of these rainfall events is likely to be lower in the future, which would reduce the chances for aquifer recharge despite their increasing size [63]. At the same time, the increasing size of these events will 
reinforce the torrential characteristic of rainfall in this region, with most water input concentrating in just a few days. The precipitation concentration is also expected to increase the frequency and length of drought periods. In addition, the soil characteristics in these areas (i.e., deforested calcareous and marly soils and with a soil surface crust) will not favour water infiltration, but will reduce soil water content (SWC), which has been pointed out as the main hydrological variable to explain the observed variations in P. halepensis growth and phenology [84,85].

\section{Conclusions}

In general, the water balance of $Q$. ilex and P. halepensis forests shows low values for blue to green water ratios in Mediterranean ecosystems. For green water, evapotranspiration and interception are the main processes, which are strongly influenced by the complexity of vegetation composition and structure. On the other hand, groundwater recharge is the only relevant flux for the blue component of the balance. The bias towards green water grows during droughts, and these conditions have a negative impact on blue water because then there are fewer rainfall events capable of producing groundwater recharge.

Adaptive management practices can be followed to compensate for this unbalance and to promote blue water fluxes. Indeed, forest thinning practices can help to reduce losses by interception, but can also increase tree transpiration and soil evaporation rates. However, these practices lead to higher blue to green ratios when considering the whole stand. These silviculture practices have also been proposed to enhance the water yield of afforestation, especially in more humid places, while their effect has less potential in dryer ones, where it does not differ much from non afforested areas.

Climate change estimations predict that arid and semiarid conditions will extend, and the water balance simulations for these scenarios show negative trends for all water balance components. All the estimated scenarios predict a marked change in deep percolation and, therefore, in groundwater recharge. The cause of this is explained mainly by the fact that rainfall events will become less frequent and only a few will reach the precipitation threshold needed to produce them. Drought conditions are also expected to intensify, which could trigger plant mortality events and species replacement, as previously observed. This scenario could alter the composition and structure of communities, which would affect their water balances. Therefore, further research is needed to better understand how these drought-induced processes will affect the sustainability and water balances of Mediterranean forests.

Finally, given the forecasted higher frequency of droughts in semiarid forests, their water demand is expected to increase, while water will become scarcer. This would threaten their stability and resources. However, management practices could be key to compensating for this impact. Hence, more in-depth knowledge of the ecohydrology of these forests and their response to drought is needed to ensure the best application of these practices.

Supplementary Materials: The following are available online at http:/ /www.mdpi.com/1999-4907/9/7/426/s1, Supplementary File: Reference list for Table 1.

Author Contributions: All authors contributed equally to this paper.

Funding: This research was partially founded by the Spanish Ministry of Economy and Competitiveness trough the projects ALTERACLIM (CGL2015-69773-C2-1-P), SURVIVE-2 (CGL2015-69773-C2-2-P MINECO/FEDER), HYDROSIL (CGL2011-28776-C02-02), SILWAMED (CGL2014-58127-C3-2), CEHYRFO-MED (CGL2017-86839-C3-2-R), INTEGRA (CGL2011-28776-C02), E-HIDROMED (CGL2014-58127-C3), and FEDER funds.

Acknowledgments: E.V. gives thanks for a predoctoral fellowship funded by the Spanish Ministry of Economy and Competitiveness within the above cited project ALTERACLIM. A.d.C. and M.G.-S. are grateful to the Valencia Regional Government (CMAAUV, Generalitat Valenciana), VAERSA, and ACCIONA for their support and assistance in carrying out the fieldwork. A.M.-A. was supported by an FPI scholarship. CEAM is supported by the Generalitat Valenciana.

Conflicts of Interest: The authors declare no conflict of interest. 


\section{References}

1. Ellison, D.; Morris, C.E.; Locatellu, B.; Sheil, D.; Cohen, J.; Murdiyarso, D.; Gutierrez, V.; van Noordwijk, M.; Creed, I.F.; Pokorny, J.; et al. Trees, forests and water: Cool insigths for a hot world. Glob. Environ. Chang. 2017, 43, 51-61. [CrossRef]

2. Rohatyn, S.; Rotenberg, E.; Ramati, E.; Tatarinov, F.; Tas, E.; Yakir, D. Differential impacts of land use and precipitation on 'Ecosystem Water Yield'. Water Resour. Res. 2018. [CrossRef]

3. Helman, D.; Lensky, I.M.; Osem, Y.; Rohatyn, S.; Rotenberg, E.; Yakir, D. A biophysical approach using water deficit factor for daily estimations of evapotranspiration and $\mathrm{CO}_{2}$ uptake in Mediterranean environments. Biogeosciences 2017, 14, 3909-3926. [CrossRef]

4. Jackson, R.B.; Jobbagy, E.G.; Avissar, R.; Roy, S.B.; Barrett, D.J.; Cook, C.W.; Farley, K.A.; le Maitre, D.C.; McCarl, B.A.; Murray, B.C. Trading water for carbon with biological carbon sequestration. Science 2005, 310, 1944-1947. [CrossRef] [PubMed]

5. Farley, K.A.; Jobbagy, E.G.; Jackson, R.B. Effects of afforestation on water yield: A global synthesis with implications for policy. Glob. Chang. Biol. 2005, 11, 1565-1576. [CrossRef]

6. Muñoz-Villers, L.E.; Holwerda, F.; Gómez-Cárdenas, M.; Equihua, M.; Asbjornsen, H.; Bruijnzeel, L.A.; Marín-Castro, B.E.; Tobón, C. Water balances of old-growth and regenerating montane cloud forests in central Veracruz, Mexico. J. Hydrol. 2012, 462-463, 53-66. [CrossRef]

7. Derak, M.; Cortina, J. Multi-criteria participative evaluation of Pinus halepensis plantations in a semiarid area of southeast Spain. Ecol. Indic. 2014, 43, 56-68. [CrossRef]

8. Ilstedt, U.; Tobella, A.B.; Bazié, H.R.; Bayala, J.; Verbeeten, E.; Nyberg, G.; Sanou, J.; Benegas, L.; Murdiyarso, D.; Laudon, H.; et al. Intermediate tree cover can maximize groundwater recharge in the seasonally dry tropics. Sci. Rep. 2016, 6, 21930. [CrossRef] [PubMed]

9. Barros, V.R.; Field, C.B.; Dokken, D.J.; Mastrandrea, M.D.; Mach, K.J.; Bilir, T.E.; Chatterjee, M.; Ebi, K.L.; Estrada, Y.O.; Genova, R.C.; et al. Climate Change 2014: Impacts, Adaptation, and Vulnerability_Part B: Regional Aspects - Contribution of Working Group II to the Fifth Assessment Report of the Intergovernmental Panel on Climate Change; Cambridge University Press: Cambridge, New York, NY, USA, 2014; p. 688.

10. Allen, C.D.; Breshears, D.D.; McDowell, N.G. On underestimation of global vulnerability to tree mortality and forest die-off from hotter drought in the Anthropocene. Ecosphere 2015, 6, 1-55. [CrossRef]

11. Hartmann, H.; Schuld, B.; Sanders, T.G.; Macinnis-Ng, C.; Boehmer, H.J.; Allen, C.D.; Bolte, A.; Crowther, T.W.; Hansen, M.C.; Medlyn, B.E.; et al. Monitoring global tree mortality patterns and trends. Report from the VW symposium 'Crossing scales and disciplines to identify global trends of tree mortality as indicators of forest health'. New Phytol. 2018, 217, 984-987. [CrossRef] [PubMed]

12. Giorgi, F. Climate change hot-spots. Geophys. Res. Lett. 2006, 33, L08707. [CrossRef]

13. Herrera, C.M. Historical effects and sorting processes as explanations for contemporary ecological patterns; character syndromes in Mediterranean woody plants. Am. Nat. 1992, 140, 421-446. [CrossRef]

14. Poyatos, R.; Aguadé, D.; Gaiano, L.; Mencuccini, M.; Martínez-Vilalta, J. Drought-induced defoliation and long periods of near-zero gas Exchange play a key role in accentuating metabolic decline of Scots pine. New Phytol. 2013, 200, 388-401. [CrossRef] [PubMed]

15. Grossiord, C.; Forner, A.; Gessler, A.; Granier, A.; Pollastrini, M.; Valladares, F.; Bonal, D. Influence of species interactions on transpiration of Mediterranean tree species during a summer drought. Eur. J. For. Restaur. 2015, 134, 365-376. [CrossRef]

16. De la Torre, J.R. Distribución y características de las masas forestales españolas. Fundación Dialnet 1990, 1, 11-30.

17. Zavala, M.A. A model of stand dynamics for holm oak-Aleppo pine forests. In Ecology of Mediterranean Evergreen Oak Forests; Rodà, F., Retana, J., Gracia, C.A., Bellot, J., Eds.; Springer: Berlin/Heidelberg, Germany, 1999; pp. 105-117.

18. Hernández, E.I.; Vilagrosa, A.; Pausas, J.G.; Bellot, J. Morphological traits and water use strategies in seedlings of Mediterranean coexisting species. Plant Ecol. 2010, 207, 233-244. [CrossRef]

19. Peguero-Pina, J.J.; Sancho-Knapik, D.; Barrón, E.; Camarero, J.J.; Vilagrosa, A.; Gil-Pelegrín, E. Morphological and physiological divergences within Quercus ilex support the existence of different ecotypes depending on climatic dryness. Ann. Bot. 2014, 114, 301-313. [CrossRef] [PubMed] 
20. Vilagrosa, A.; Hernández, E.I.; Luis, V.C.; Cochard, H.; Pausas, J.G. Physiological differences explain the co-existence of different regeneration strategies in Mediterranean ecosystems. New Phytol. 2014, 201, 1277-1288. [CrossRef] [PubMed]

21. Peìrez-Harguindeguy, N.; Díaz, S.; Garnier, E.; Lavorel, S.; Poorter, H.; Jaureguiberry, P.; Bret-Harte, M.S.; Cornwell, W.K.; Craine, J.M.; Gurvich, D.E.; et al. New handbook for standardised measurement of plant functional traits worldwide. Aust. J. Bot. 2013, 61, 167-234. [CrossRef]

22. Cayuela, C.; Llorens, P.; Sánchez-Costa, E.; Levia, D.; Latron, J. Effect of biotic and abiotic factors on inter- and intra-event variability in stemflow rates in oak and pine stands in a Mediterranean mountain area. J. Hydrol. 2018, 560, 396-406. [CrossRef]

23. Bellot, J.; Chirino, E. Hydrobal: An eco-hydrological modelling approach for assessing water balances in different vegetation types in semi-arid areas. Ecol. Model. 2013, 266, 30-41. [CrossRef]

24. Chirino, E.; Vilagrosa, A.; Hernández, E.I.; Matos, A.; Vallejo, V.R. Effects of a deep container on morpho-functional characteristics and root colonization in Quercus suber L. seedlings for reforestation in Mediterranean climate. For. Ecol. Manag. 2008, 256, 779-785. [CrossRef]

25. Van der Plas, F.; Manning, P.; Soliveres, S.; Allan, E.; Scherer-Lorenzen, M.; Verheyen, K.; Wirth, C.; Zavala, M.A.; Ampoorter, E.; Baeten, L.; et al. Biotic homogenization can decrease landscape-scale forest multifunctionality. Proc. Natl. Acad. Sci. USA 2016, 113, 3557-3562. [CrossRef] [PubMed]

26. Pemán, J.; Voltas, J.; Gil Pelegrín, E. Morphological and functional variability in the root system of Quercus ilex L. subject to confinement: Consequences for afforestation. Ann. For. Sci. 2006, 63, 425-430. [CrossRef]

27. Bellot, J.; Escarre, A. Stemflow and throughfall determination in a resprouted Mediterranean holm-oak forest. Ann. For. Sci. 1998, 55, 847-865. [CrossRef]

28. Helman, D.; Osem, Y.; Yakir, D.; Lensky, I.M. Relationships between climate, topography, water use and productivity in two key Mediterranean forest types with different water-use strategies. Agric. For. Meteorol. 2017, 232, 319-330. [CrossRef]

29. Levitt, J. Responses of Plants to Environmental Stresses; Academic Press: New York, NY, USA, 1980; Volume 2.

30. Tardieu, F.; Simonneau, T. Variability among species of stomatal control under fluctuating soil water status and evaporative demand: Modelling isohydric and anisohydric behaviours. J. Exp. Bot. 1998, 49, 419-432. [CrossRef]

31. McDowell, N.; Pockman, W.T.; Allen, C.D.; Breshears, D.; Cobb, N.; Kolb, T.; Plaut, P.; West, J.A.; Williams, D.G.; Yepez, E.A. Mechanisms of plant survival and mortality during drought: Why do some plants survive while others succumb to drought? New Phytol. 2008, 178, 719-739. [CrossRef] [PubMed]

32. Grossiord, C.; Sevanto, S.; Borrego, I.; Chen, A.M.; Collins, A.D.; Dickman, L.T.; Hudson, P.J.; McBranch, N.; Michaletz, S.T.; Pockman, W.T.; et al. Tree water dynamics in a drying and warming world. Plant Cell Environ. 2017, 40, 1861-1873. [CrossRef] [PubMed]

33. Klein, T. The variability of stomatal sensitivity to leaf water potential across tree species indicates a continuum between isohydric and anisohydric behaviours. Funct. Ecol. 2014, 28, 1313-1320. [CrossRef]

34. Martínez-Vilalta, J.; Garcia-Forner, N. Water potential regulation, stomatal behaviour and hydraulic transport under drought: Deconstructing the iso/anisohydric concept. Plant Cell Environ. 2016, 40, 962-976. [CrossRef] [PubMed]

35. Carmona, A.V. Estrategias De Resistencia Al Déficit Hídrico En Pistacia lentiscus L. Y Quercus coccifera L. Implicaciones En La Repoblación Forestal. Ph.D. Thesis, Universidad de Alicante, Alicante, Spain, 2002.

36. Martínez-Ferri, E.; Balaguer, L.; Valladares, F.; Chico, J.M.; Manrique, E. Energy dissipation in drought-avoiding and drought tolerant tree species at midday during the Mediterranean summer. Tree Physiol. 2000, 20, 131-138. [CrossRef] [PubMed]

37. Chirino, E.; Bellot, J.; Sánchez, J.R. Daily sap flow rate as an indicator of drought avoidance mechanisms in five Mediterranean perennial species in semi-arid southeastern Spain. Trees 2011, 25, 593-606. [CrossRef]

38. Ruiz-Yanetti, S.; Chirino, E.; Bellot, J. Daily whole-seedling transpiration determined by minilysimeters, allows the estimation of the water requirements of seedlings used for dryland afforestation. J. Arid Environ. 2016, 124, 341-351. [CrossRef]

39. Klein, T.; Shpringer, I.; Fikler, B.; Elbaz, G.; Cohen, S.; Yakir, D. Relationships between stomatal regulation, water-use, and water-use efficiency of two coexisting key Mediterranean tree species. For. Ecol. Manag. 2013, 302, 34-42. [CrossRef] 
40. Liniger, H.P.; Weingartner, R. Mountain Forests and Their Role in Providing Freshwater Resources; CABI Publishing, in association with IUFRO (International Union for Forestry Research Organizations): Wallingford, UK; New York, NY, USA, 2000.

41. Limousin, J.M.; Rambal, S.; Ourcival, J.M.; Rocheteau, A.; Joffre, R.; Rodríguez-Cortina, R. Long-term transpiration change with rainfall decline in a Mediterranean Quercus ilex forest. Glob. Chang. Biol. 2009, 15, 2163-2175. [CrossRef]

42. Joffre, R.; Rambal, S. How tree cover influences the water balance of Mediterranean rangelands. Ecology 1993, 74, 570-582. [CrossRef]

43. Ceballos, A.; Schnabel, S. Hydrological behaviour of a small catchment in the dehesa landuse system (Extremadura, SW Spain). J. Hydrol. 1998, 210, 146-160. [CrossRef]

44. Campos, I.; González-Piqueras, J.; Carrara, A.; Villodre, J.; Calera, A. Estimation of total available water in the soil layer by integrating actual evapotranspiration data in a remote sensing-driven soil water balance. J. Hydrol. 2016, 534, 427-439. [CrossRef]

45. Del Campo, A.; González-Sanchis, M.; Garcia-Prats, A.; Ceacero, C.J.; Lull, C. The impact of adaptive forest management on water fluxes and growth dynamics in a water-limited low-biomass oak coppice. Agric. For. Meteorol. 2018. submitted for publication.

46. González-Sanchis, M.; Del Campo, A.D.; Molina, A.J.; Fernandes, T.J.G. Modeling adaptive forest management of a semi-arid Mediterranean Aleppo pine plantation. Ecol. Model. 2015, 308, 34-44. [CrossRef]

47. Paço, T.A.; David, T.S.; Henriques, M.O.; Pereira, J.S.; Valente, F.; Banza, J.; Pereira, F.L.; Pinto, C.; David, J.S. Evapotranspiration from a Mediterranean evergreen oak savannah: The role of trees and pasture. J. Hydrol. 2009, 369, 98-106. [CrossRef]

48. Infante, J.M.; Domingo, F.; Alés, R.F.; Joffre, R.; Rambal, S. Quercus ilex transpiration as affected by a prolonged drought period. Biol. Plant. 2003, 46, 49-55. [CrossRef]

49. Schiller, G.; Cohen, Y. Water balance of Pinus halepensis Mill. afforestation in an arid region. For. Ecol. Manag. 1998, 105, 121-128. [CrossRef]

50. Ungar, E.D.; Rotenberg, E.; Raz-Yaseef, N.; Cohen, S.; Yakir, D.; Schiller, G. Transpiration and annual water balance of Aleppo pine in a semiarid region: Implications for forest management. For. Ecol. Manag. 2013, 298, 39-51. [CrossRef]

51. Raz-Yaseef, N.; Yakir, D.; Schiller, G.; Cohen, S. Dynamics of evapotranspiration partitioning in a semi-arid forest as affected by temporal rainfall patterns. Agric. For. Meteorol. 2012, 157, 77-85. [CrossRef]

52. Barbeta, A.; Mejia-Chang, M.; Ogaya, R.; Voltas, J.; Dawson, T.E.; Penuelas, J. The combined effects of a long-term experimental drought and an extreme drought on the use of plant-water sources in a Mediterranean forest. Glob. Chang. Biol. 2015, 21, 1213-1225. [CrossRef] [PubMed]

53. Rotenberg, E.; Yakir, D. Distinct patterns of changes in surface energy budget associated with forestation in the semiarid region. Glob. Chang. Biol. 2011, 17, 1536-1548. [CrossRef]

54. Tatarinov, F.; Rotenberg, E.; Maseyk, K.; Ogee, J.; Klein, T.; Yakir, D. Resilience to seasonal heat wave episodes in a Mediterranean pine forest. New Phytol. 2016, 210, 485-496. [CrossRef] [PubMed]

55. Helman, D.; Lensky, I.M.; Yakir, D.; Osem, Y. Forests growing under dry conditions have higher hydrological resilience to drought than do more humid forests. Glob. Chang. Biol. 2017, 23, 2801-2817. [CrossRef] [PubMed]

56. Maseyk, K.S.; Lin, T.; Rotenberg, E.; Grünzweig, J.M.; Schwartz, A.; Yakir, D. Physiology-phenology interactions in a productive semi-arid pine forest. New Phytol. 2008, 178, 603-616. [CrossRef] [PubMed]

57. Ruiz-Yanetti, S. Respuesta A La Sequía De Especies Y Comunidades De Ambientes Contrastados: Comparación De Balances Hídricos. Ph.D. Thesis, University of Alicante, Alicante, Spain, 2017.

58. Bellot, J.; Sanchez, J.R.; Chirino, E.; Hernandez, N.; Abdelli, F.; Martinez, J.M. Effect of different vegetation type cover on the soil water balance in semi-arid areas of south eastern Spain. Phys. Chem. Earth (B) 1999, 24, 353-357. [CrossRef]

59. Bellot, J.; Bonet, A.; Sánchez, J.R.; Chirino, E. Likely effects of land use changes on the runoff aquifer recharge in a semiarid landscape using a hydrological model. Landsc. Urban Plan. 2001, 55, 41-53. [CrossRef]

60. Chirino, E. Influencia De Las Precipitaciones Y De La Vegetación En El Balance Hídrico Superficial Y La Recarga De Acuíferos En Clima Semiárido. Ph.D. Thesis, Universidad de Alicante, Alicante, Spain, 2003. 
61. Llorens, P.; Latron, J.; Gallart, F. Dinámica Espacio-Temporal de la Humedad del Suelo en un Área de Montaña Mediterránea. Cuencas Experimentales de Vallcebre (Alto Llobregat). Available online: https://www. researchgate.net/profile/Pilar_Llorens/publication/268401867_DINAMICA_ESPACIO-TEMPORAL_ DE_LA_HUMEDAD_DEL_SUELO_EN_UN_AREA_DE_MONTANA_MEDITERRANEA_CUENCAS_ EXPERIMENTALES_DE_VALLCEBRE_ALTO_LLOBREGAT/links/55ed9e0d08ae21d099c77243/ DINAMICA-ESPACIO-TEMPORAL-DE-LA-HUMEDAD-DEL-SUELO-EN-UN-AREA-DE-MONTANAMEDITERRANEA-CUENCAS-EXPERIMENTALES-DE-VALLCEBRE-ALTO-LLOBREGAT.pdf (accessed on 1 June 2018).

62. Nisbet, T. Water Use by Tree. Available online: https://www.forestry.gov.uk/pdf/FCIN065.pdf/\$FILE/ FCIN065.pdf (accessed on 1 June 2018).

63. Moutahir, H.; Bellot, P.; Monjo, R.; Bellot, J.; Garcia, M.; Touhami, I. Likely effects of climate change on groundwater availability in a Mediterranean region of Southeastern Spain. Hydrol. Process. 2017, 31, 161-176. [CrossRef]

64. Carrera-Hernandez, J.J.; Gaskin, S.J. Spatio-temporal analysis of potential aquifer recharge: Application to the basin of Mexico. J. Hydrol. 2008, 353, 228-246. [CrossRef]

65. Touhami, I.; Andreu, J.M.; Chirino, E.; Sánchez, J.R.; Moutahir, H.; Pulido-Bosch, A.; Martínez-Santos, P.; Bellot, J. Recharge estimation of a small karstic aquifer in a semiarid Mediterranean region (Southeastern Spain) using a hydrological model. Hydrol. Process. 2013, 27, 165-174. [CrossRef]

66. Andreu, J.M.; Delgado, J.; García-Sánchez, E.; Pulido-Bosch, A.; Bellot, J.; Chirino, E.; Ortíz de Urbina, J.M. Caracterización del funcionamiento y la recarga del acuífero del Ventós-Castellar (Alicante). Revista de la Sociedad Geológica de España 2001, 14, 247-254.

67. Osem, Y.; O'Hara, K. An ecohydrological approach to managing dryland forests: Integration of leaf area metrics into assessment and management. Forestry 2016, 89, 338-349. [CrossRef]

68. Del Campo, A.D.; Fernandes, T.J.G.; Molina, A.J. Hydrology-oriented (adaptive) silviculture in a semiarid pine plantation: How much can be modified the water cycle through forest management? Eur. J. For. Res. 2014, 133, 879-894. [CrossRef]

69. Molina, A.J.; del Campo, A.D. The effects of experimental thinning on throughfalland stemflow: A contribution towards hydrology-oriented silviculture in Aleppopine plantations. For. Ecol. Manag. 2012, 269, 206-213. [CrossRef]

70. Bellot, J.; Maestre, F.T.; Chirino, E.; Hernández, N.; de Urbina, J.O. Afforestation with Pinus halepensis reduces native shrub performance in a Mediterranean semiarid area. Acta Oecol. 2004, 25, 7-15. [CrossRef]

71. Rodríguez-Robles, U.; Arredondo, J.T.; Huber-Sannwald, E.; Vargas, R. Geoecohydrological mechanisms couple soil and leaf water dynamics and facilitate species coexistence in shallow soils of a tropical semiarid mixed forest. New Phytol. 2015, 207, 59-69. [CrossRef] [PubMed]

72. Del Castillo, J.; Comas, C.; Voltas, J.; Ferrio, J.P. Dynamics of competition over water in a mixed oak-pine Mediterranean forest: Spatio-temporal and physiological components. For. Ecol. Manag. 2016, 382, $214-224$. [CrossRef]

73. David, T.S.; Henriques, M.O.; Kurz-Besson, C.; Nunes, J.; Valente, F.; Vaz, M.; Pereira, J.S.; Siegwolf, R.; Chaves, M.M.; Gazarini, L.C.; et al. Water-use strategies in two co-occurring Mediterranean evergreen oaks: Surviving the summer drought. Tree Physiol. 2007, 27, 793-803. [CrossRef] [PubMed]

74. Voltas, J.; Lucabaugh, D.; Chambel, M.R.; Ferrio, J.P. Intraspecific variation in the use of water sources by the circum-Mediterranean conifer Pinus halepensis. New Phytol. 2015, 208, 1031-1041. [CrossRef] [PubMed]

75. Nambiar, E.K.S. Interplay between nutrients, water, root growth and productivity in young plantations. For. Ecol. Manag. 1990, 30, 213-232. [CrossRef]

76. Querejeta, J.I.; Roldán, A.; Albaladejo, J.; Castillo, V. Soil water availability improved by site preparation in a Pinus halepensis afforestation under semiarid climate. For. Ecol. Manag. 2001, 149, 115-128. [CrossRef]

77. Klein, T.; Rotenberg, E.; Cohen-Hilaleh, E.; Raz-Yaseef, N.; Tatarinov, F.; Preisler, Y.; Ogée, G.; Cohen, S.; Yakir, D. Quantifying transpirable soil water and its relations to tree water use dynamics in a water-limited pine forest. Ecohydrology 2014, 7, 409-419. [CrossRef]

78. Moreno, J.M. A Preliminary Assessment of the Impacts in Spain Due to the Effects of Climate Change; ECCE Project-Final Report; Spanish Ministry of Environment-University of Castilla de la Mancha: Madrid, Spain, 2005; p. 786.

79. Gonzalez-Hidalgo, J.C.; Peña-Angulo, D.; Simolo, C.; Brunetti, M.; Cortesi, N. Variación Espacial de las Tendencias de los Promedios Estacionales de las Máximas y de las Mínimas en España (1951-2010); Asociación Española de Climatología: Almería, Spain, 2014; pp. 99-108. 
80. Moutahir, H. Likely Effects of Climate Change on Water Resources and Vegetation Growth Period in the Province of Alicante, Southeastern Spain. Ph.D. Thesis, University of Alicante, Alicante, Spain, 2016.

81. Rivas-Martínez, S. Pisos bioclimáticos de España. Lazaroa 1983, 5, 33-43.

82. Rubel, F.; Kottek, M. Observed and projected climate shifs 1901-2100 depicted by world maps of Köppen-Geiger climate classification. Meteorol. Z. 2010, 19, 135-141. [CrossRef]

83. Tweed, S.; Leblanc, M.; Cartwright, I.; Favreau, G.; Leduc, C. Arid zone groundwater recharge and salinisation processes; an example from the Lake Eyre Basin, Australia. J. Hydrol. 2011, 408, 257-275. [CrossRef]

84. Manrique-Alba, À.; Ruiz-Yanetti, S.; Moutahir, H.; Novak, K.; De Luis, M.; Bellot, J. Soil moisture and its role in growth-climate relationships across an aridity gradient in semiarid Pinus halepensis forests. Sci. Total Environ. 2017, 574, 982-990. [CrossRef] [PubMed]

85. Moutahir, H.; Casady, G.; Manrique-Alba, A.; Ruiz-Yanetti, S.; Maturano, A.; Zeramdini, A.; Bellot Abad, J. Can we better understand land surface phenology changes using hydrological variables instead of climate variables? In Proceedings of the XIV MEDECOS \& XIII AEET Meeting, Seville, Spain, 31 January-4 February 2017.

(C) 2018 by the authors. Licensee MDPI, Basel, Switzerland. This article is an open access article distributed under the terms and conditions of the Creative Commons Attribution (CC BY) license (http://creativecommons.org/licenses/by/4.0/). 